\section{Evaluation of digital periapical radiographs obtained by dental students}

\section{Diş hekimliği öğrencileri tarafından alınan dijital periapikal radyografilerin kalite değerlendirilmesi}

\section{Assist. Prof. Nilüfer Ersan}

Yeditepe University, Faculty of Dentistry, Department of Dentomaxillofacial Radiology, Istanbul, Turkey.

\section{Assoc. Prof. Zehra Semanur Dölekoğlu}

Yeditepe University, Faculty of Dentistry, Department of Dentomaxillofacial Radiology, Istanbul, Turkey.

\section{Assoc. Prof. Erdoğan Fişekçioğlu}

Yeditepe University, Faculty of Dentistry, Department of Dentomaxillofacial Radiology, Istanbul, Turkey.

Prof. Dilhan ilgüy

Yeditepe University, Faculty of Dentistry, Department of Dentomaxillofacial Radiology, Istanbul, Turkey.

Received: 7 July 2016

Accepted: 18 August 2016

DOI: 10.5505/yeditepe.2016.96168

Corresponding author:

Assist. Prof. Nilüfer Ersan

Yeditepe University, Faculty of Dentistry, Department of Dentomaxillofacial Radiology, Istanbul, Turkey. Bağdat Cad. No: 238/3/A 34728, Goztepe, Istanbul, Turkey

Tel: +90 2163636044 / 6414

Fax: +90 2163636211

Email: nilufer.ersan@yeditepe.edu.tr

\section{SUMMARY}

Aim: The aim of this study was to evaluate the quality of digital periapical radiographs obtained using bisecting angle technique by 3 rd grade dental students, who were theoretically taught on paralleling and bisecting angle techniques and had the practical experience only for the paralleling technique on dental phantom models.

Materials and Methods: The quality digital periapical radiographs, taken with photostimulable phosphor plates (PSPs) by 3 rd year dental students during the initial examination, was evaluated. The type of the teeth, errors on the radiographs related with angulation of the tube head, placement and exposure of the film, and the radiographs, which needed repetition, were recorded.

Results: Overall 288 digital periapical radiographs (53 maxillary anterior, 26 mandibular anterior, 109 maxillary posterior, 100 mandibular posterior) were evaluated. The percentage of radiographs that needed repetition was found as $13.5 \%$. The percentage of positioning errors related to the visibility of the apex was $20,1 \%$. The percentage of the presence of conecut was $28,1 \%$. Overall rate of angulation error was found to be $36,8 \%$.

Conclusions: The need for repetition of periapical radiographs taken by 3rd grade dental students seems to be high. Evaluation of the clinical performance of the dental students is needed to identify the deficiencies in teaching/learning process, and for improvement of the dentomaxillofacial radiology curriculum and provision of patient safety. Dental curriculum should be revised, so that the practical courses including bisecting angle technique as well as paralleling technique was taught both theoretically and practically.

Key words: Clinical evaluation, digital radiography, undergraduate dental education.

\section{ÖZET}

Amaç: Bu çalışmanın amacı, paralel ve açıortay tekniklerini teorik olarak öğrenen ancak pratik eğitimde dental fantom model üzerinde yalnızca paralel tekniği kullanan 3. sınıf diş hekimliği öğrencileri tarafından açıortay tekniği kullanılarak alınan dijital periapikal radyografilerin kalitesinin değerlendirilmesidir.

Gereç ve Yöntem: Illk muayene sırasında 3. sınıf öğrencileri tarafından fosfor plaklar ile açırtay tekniği kullanılarak alınan dijital periapikal radyografilerin kalitesi değerlendirildi. Işın kaynağının açısı, filmin yerleştirilmesi ve ışınlanması ile ilgili radyografi hataları, tekrar gerektiren radyografiler ve radyografisi alınan dişlerin tipi kaydedildi.

Bulgular: Bu çalışmada 288 dijital periapikal radyografi (53 maksiller anterior, 26 mandibular anterior, 109 maksiller posterior, 100 mandibular posterior) değerlendirilmiștir. Tekrar gerektiren radyografi oranı $\% 13,5$ olarak bulunmuştur. İlgili diş kökünün tümüyle görüntülenememesine bağlı 
hata, radyografilerin \%20.1'inde görülmüştür. 'Cone-cut' görülme oranı \%28.1 iken, açılandırma hatası radyografilerin \%36,8'inde gözlemlenmiştir.

Sonuç: Bu çalışmada 3. sınıf öğrencilerinin aldığı radyografilerde tekrar oranı yüksek bulunmuştur. Öğrencilerin klinik performanslarının değerlendirilmesi eğitim sürecindeki eksikliklerin belirlenmesi, müfredatın geliştirilmesi ve hasta güvenliğinin sağlanması açısından önemlidir. Müfredat açıortay tekniğinin de pratik eğitime katılmasını içerecek şekilde değiştirilmelidir.

Anahtar kelimeler: Klinik değerlendirme, dijital radyografi, diş hekimliği eğitimi.

\section{INTRODUCTION}

Intraoral radiographic examination is the backbone of dental imaging. The Commission on Dental Accreditation states that graduates must be competent in obtaining diagnostic intraoral radiographs. ${ }^{1}$ Previous recommendations concerning image quality and the interpretation of the radiographic image have been made by some organizations..$^{2-4}$ After having dental radiology education, a student should know how the periapical radiographs are formed, evaluate the accuracy of the image generated and be familiar with image distortion characteristics of common technique errors and projection artifacts. ${ }^{5}$

Periapical radiograph, which is a main part of intraoral radiographic examination, should show all of a tooth, including at least $2 \mathrm{~mm}$ of the surrounding periapical bone. ${ }^{6}$ The bisecting angle technique, when taken appropriately, reduces magnification and increases image sharpness as a result of placing the film closer to the teeth than in paralleling technique. However, since the bisecting angle technique is more prone to shape distortion, paralleling technique is the main technique being taught in dental radiology courses.

There are studies that have reported the type and frequency of errors incurred when radiographs were taken by students. ${ }^{7-9}$ Assessment of the learning outcomes, may give information about the competencies, which a dental student should have. Clinical performance of the student should also be monitored regularly and feedback is important to develop the students' skills. In order to improve the radiological practical and theoretical curriculum, one of the assessment methods is to evaluate the students' clinical performance.

The aim of this study was to evaluate the quality of digital periapical radiographs obtained using bisecting angle technique by $3^{\text {rd }}$ grade dental students, who were theoretically taught on paralleling and bisecting angle techniques and had the practical experience only for the paralleling technique on dental phantom models.

\section{MATERIALS AND METHODS}

The research was conducted according to the principles of the Declaration of Helsinki. The quality of digital periapical radiographs obtained during the academic years of 2014-2015 and 2015-2016 by 3rd year dental students using bisecting angle technique was evaluated. During the initial examination of the patients, who presented to the multidisciplinary student clinics for dental treatment, digital periapical images were obtained with a Trophy (Novalix, Croissy-Beaubourg- France; operating at 65 $\mathrm{kV}, 8 \mathrm{~mA}$ ) intra-oral X-ray unit, as well as photostimulable phosphor plates (PSPs) with Digora Optime (Soredex, Milwaukee, WI), where indicated. A written consent was taken from each subject in the study before exposure.

The radiographs that were considered as having optimal diagnostic quality were those: full length of the roots and at least $2 \mathrm{~mm}$ of periapical bone must be visible (for periapical radiographs), as well as presence of sharpness or detail, minimal distortion, correct film positioning, lack of artifacts, optimal density and contrast. ${ }^{1}$ The radiographs, which did not meet these criteria, were accepted to have errors, which could lead to the repetition of the radiograph in accordance with the clinical need.

Teeth were classified as maxillary and mandibular anteriors (maxillary and mandibular incisors and canines), maxillary and mandibular posteriors (maxillary and mandibular premolars and molars). The radiographs were evaluated with respect to the positioning and technical errors. Angulation of the tube head was subdivided as vertical and horizontal. Vertical angulation: Lengthening and/or shortening of image. Horizontal angulation: Image overlapping, preventing or making difficult X-ray interpretation. Film and/or x-ray beam positioning: Off-centered image, crown/root cut off or an area of film not exposed to radiation (cone cut). Exposure errors: over/ under/correct exposure related to the tooth region. Finally, radiographic acceptance (diagnostic acceptability/ repetition of the radiograph) was decided according to conditions mentioned above and the radiographs, which needed repetition, were recorded. In order to avoid the potential damage of radiation, repetition of the radiographs were performed only for once and under the direct supervision of the clinical assistant.

\section{RESULTS}

Overall 288 digital periapical radiographs were analyzed. The distribution of the radiographs according to the type of teeth and the percentages of the types of errors encountered on the radiographs obtained by $3^{\text {rd }}$ year dental students were shown on Table 1. The percentage of the inadequate (requiring repetition) radiographs was found as $13.5 \%$. Among the 39 radiographs, which needed repetition, the percentages of most frequently recorded er- 
rors were as follows: off-centered image (82.1\%), root cut off $(71.8 \%)$, vertical angulation $(31.6 \%)$, and lack of parallelization (56.4\%).

Table 1. The distribution of the radiographs according to the type of teeth and the percentages of the types of errors encountered on the radiographs obtained by 3rd year dental students.

\begin{tabular}{|c|c|c|c|c|c|c|}
\hline \multicolumn{2}{|l|}{$\begin{array}{c}\text { Types of } \\
\text { Errors }\end{array}$} & $\begin{array}{l}\text { Maxillary } \\
\text { Anterior } \\
\mathbf{n}=\mathbf{5 3}(\%)\end{array}$ & $\begin{array}{c}\text { Mandibular } \\
\text { Anterior } \\
\mathrm{n}=\mathbf{2 6}(\%)\end{array}$ & $\begin{array}{c}\text { Maxillary } \\
\text { Posterior } \\
\mathrm{n}=109(\%)\end{array}$ & $\begin{array}{c}\text { Mandibular } \\
\text { Posterior } \\
\text { n=100 }(\%)\end{array}$ & $\begin{array}{c}\text { Total } \\
\text { n=288 }(\%)\end{array}$ \\
\hline \multirow{3}{*}{ Angulation } & Horizontal & $1(1.9)$ & $0(0.0)$ & $10(9.1)$ & $4(4)$ & $15(5.2)$ \\
\hline & Vertical & $20(37.7)$ & $6(23.1)$ & $30(27.5)$ & $18(18)$ & $74(25.7)$ \\
\hline & $\begin{array}{c}\text { Horizontal \& } \\
\text { Vertical }\end{array}$ & $1(1.9)$ & $0(0.0)$ & $14(12.8)$ & $2(2)$ & $17(5.9)$ \\
\hline \multicolumn{2}{|l|}{ Cone-cut } & $9(17.0)$ & $5(19.2)$ & $40(36.7)$ & $27(27)$ & $81(28.1)$ \\
\hline \multicolumn{2}{|l|}{ Parallelization } & $15(28.3)$ & $3(11.5)$ & $53(48.6)$ & $27(27)$ & $98(34.0)$ \\
\hline \multicolumn{2}{|l|}{ Exposure } & $9(17.0)$ & 3 (11. & $15(13.8)$ & $12(12)$ & $39(13.5)$ \\
\hline \multicolumn{2}{|l|}{ Focus } & $12(22.6)$ & $5(19.2)$ & $30(27.5)$ & $22(22)$ & $69(23.9)$ \\
\hline \multirow{2}{*}{ Visualization } & Root & $11(20.7)$ & $5(19.2)$ & $25(22.9)$ & $17(17)$ & $58(20.1)$ \\
\hline & Crown & $4(7.5)$ & $3(11.5)$ & $12(11.0)$ & $11(11)$ & $30(10.4)$ \\
\hline \multicolumn{2}{|l|}{ Repetition } & $7(13.2)$ & $1(3.8)$ & $21(19.3)$ & $10(10)$ & $39(13.5)$ \\
\hline
\end{tabular}

\section{DISCUSSION}

The dental student must understand the goals of dental radiography and the criteria for evaluating the quality of performance. With regard to dental radiology and imaging, there are standards expected of a dental student upon graduation. Only the $3^{\text {rd }}$ year students receive undergraduate dental radiology lectures for the whole year (32 hours). In the first semester, for the practice of dental radiology, $3^{\text {rd }}$ year students take periapical radiographs by using paralleling technique on a phantom head. In the second semester, they attend oral diagnosis and radiology rotation at the multidisciplinary clinics, which includes clinical examination, as well as taking intraoral radiographs when indicated. At the multidisciplinary students clinic, for taking digital periapical radiographs in some cases due to anatomical factors, students were obliged to use the bisecting angle technique, instead of paralleling technique during the first examination of the patients. Most of the radiographic errors may lead to misdiagnosis. Previous studies on the prevalence of radiographic errors used different methods to evaluate the quality of radiographs. ${ }^{7-14}$ In the present study, among the inadequate radiographs in need of repetition, the most frequently recorded positioning errors were off-centered image and root cut off. These results were found to be different than the results of the previous studies reported off-centered and root cut-off radiographs as $55.4 \%$ and $9.31 \%$, respectively. ${ }^{10,11}$ This may be attributed to the variations in the year of the students and the evaluation criteria.

The percentage of cone-cut error was reported in previous studies ranging between $3.15 \%$ and $26.1 \% .^{7-9,11}$ In the present study, $28.1 \%$ of the digital periapical radiographs obtained by $3^{\text {rd }}$ year students displayed presence of cone-cut. The different techniques in taking the radiographs (bisecting or paralleling) and the usage of film-holder may be responsible for the variability of results. The film positioning devices should be considered to decrease these kinds of the errors, where applicable. Incorrect vertical angulation was observed more often on radiographs of the upper teeth. This result is not consistent with the previous studies which reported that the improper vertical angulation was more common in the lower anterior teeth area..$^{10,15}$ Similarly to the previously published papers, in the present study, horizontal angulation errors were detected less often than the vertical angulation errors. ${ }^{79,10}$ Horizontal angulation errors become very important when the main objective of the radiological examination was the observation of proximal surfaces of the teeth. It was reported that, horizontal angulation errors were common on radiographs of maxillary posterior teeth ${ }^{10}$, similar with the data in the present study.

The percentage of errors regarding exposure of the radiographs was found to be $13.5 \%$ in our study. In the multidisciplinary clinic, this error did not have much effect on the retake decision of the radiographs because the brightness and contrast enhancement tool could be used for the best view of digital images.

Regular clinical performance assessment and quick feedback about student performance can play a major role in the development of the educational processes. The assessment should also relate to the student's strengths and weaknesses. Competency-based learning focuses on developing professional skills necessary to provide comprehensive patient care. These competencies should not be based on individual comparisons, but on the ability to provide adequate patient care based on global standards. High quality of radiographs can be obtained by taking optimal images and retake of the images can prevent unnecessary exposure to the patients. It should be taken into consideration that in terms of radiation protection, the amount of repetition of the inadequate radiographs was limited to only once and under the direct supervision of the clinical assistant.

This study was carried on students of only one dental school and the results might be different if more dental schools were involved. Low sample size can also be regarded as another limitation of this study.

\section{CONCLUSIONS}

The need for repetition of periapical radiographs taken by $3^{\text {rd }}$ grade dental students seems to be high. Evaluation of the clinical performance of the dental students is needed to identify the deficiencies in teaching/learning process. Also, it is important for the improvement of the dentomaxillofacial radiology curriculum and provision of patient safety. Dental curriculum should be revised, so that the practical courses including bisecting angle technique as well as paralleling technique was taught both theoretically and practically. 


\section{REFERENCES}

1. ADA (American Dental Association), Commission on Dental Accreditation. Accreditation standards for dental education facilities. Chicago 1988;16.

2. ADA (American Dental Association), Commissionon Dental Accreditation. Accreditation standards for dental education programs. Chicago, 1998, IL; c1995-2007 (updated 2005 Mar 14; cited 2007 Aug 29).

3. ADEA (American Dental Education Association). Competencies for the new dentist. J Dent Educ 2006;70:757759.

4. FGDP (The Faculty of General Dental Practice). Key skills in primary dental care: the indispensible e-learning package. London, UK, 2007. (updated 2007 Jul 26; cited 2007 Aug 29).

5. Razmus TF, Williamson GF, Van Dis ML. Assessment of the knowledge of graduating American dental students about the panoramic image. Oral Surg Oral Med Oral Pathol 1993;76:397-402.

6. White S, Pharoah MJ. Oral Radiology Principles and Interpretation. 6th ed. Mosby Elsevier; 2009.

7. Mourshed $F$. The undergraduate dental radiology curriculum. J Dent Educ 1979;43:680-682.

8. Patel JR. Intraoral radiographic errors. Oral Surg Oral Med Oral Pathol 1979;48:479-483.

9. Patel JR, Greer DF. Evaluating student progress through error reduction in intraoral radiographic technique. Oral Surg Oral Med Oral Pathol 1986;62:471-474.

10. Felippe MCS, Nassri MRG, Burgos PG, de Freitas SFT, Lage-Marques JL. Qualidade de radiografias periapicais realizadas por graduandos durante o tratamento endodôntico. / Quality of periapical radiographs taken by undergraduate students during endodontic treatment. RSBO 2009;6:63-69.

11. de Carvalho PL, Neves ACC, de Medeiros JMF, Zöllner NA, Rosa LCL, de Carvalho Almedia ETDC. Technical errors in intraoral radiographs performed by undergraduate students. / Erros técnicos nas radiografias intrabucais realizadas por alunos de graduação. RGO 2009;57:151155.

12. Fortier AP. Common errors in dental radiography. J Dent Educ 1979;43:683-684.

13. Gasparini D, Vaz EMS, Haiter Neto F, Boscolo FN. Analysis of radiographical errors performed by students of the Faculdade de Odontologia de Piracicaba, in the period of 1975 to 1988. / Análise de erros radiográficos cometidos por alunos da Faculdade de Odontologia de Piracicaba, no período de 1975a 1988. Rev Odontol Univ São Paulo 1992;6:107-114.

14. dos Anjos Pontual ML, Veloso HHP, dos Anjos Pontual A, da Fonseca Silveira MM. Intrabucal radiographs errors made at Pernambuco dental school-Brazil. / Errores en radiografias intrabucales realizadas en la facultad de odontologia de Pernambuco - Brasil. Acta Odontol Venez 2005;43:19-24.

15. Eliasson S, Lavstedt S, Wouters F, Östlin L. Quality of intraoral radiographs sent by private dental practitioners for therapy evaluation by the Social Insurance Office. Swed Dent J 1990;14:81-88. 